\title{
Confocal microscopy findings after endothelial transplant by DSAEK
}

\author{
Hallazgos mediante microscopía confocal en trasplante endotelial mediante DSAEK
}

Manuel Ramírez*, Claudia Ortiz, Guillermo Dewit-Carter and Everardo Hernández-Quintela

Department of Cornea and Refractive Surgery, Asociación para Evitar la Ceguera en México, Hospital Luis Sánchez Bulnes, Universidad Nacional Autónoma de México, Mexico City, Mexico

\begin{abstract}
Objective: To evaluate early in vivo corneal wound healing findings after Descemet's Stripping Automated Endothelial Keratoplasty (DSAEK) by using in vivo confocal microscopy. Method: $A$ total of 15 eyes of 15 patients were included. In vivo confocal microscopy (Confoscan 4, Fortune Technologies, Italy) was performed from 4 to 7 weeks after DSAEK. Measurements were scanned from the corneal endothelium to the corneal surface with a Navis $®$ software (NIDEK, Multi-Instrument Diagnostic System, Japan). Results: Donor-receptor interface was found in an average of $114 \pm 12.4$ microns. Corneal stromal folds were observed from $111.1 \pm 3.5$ microns from the endothelium to $286 \pm 94$ microns (mean $175 \pm 90.5$ microns of the corneal stroma). Keratocites were activated in the donor tissue from $12 \pm 1.4$ microns from the endothelium to $105 \pm 38.2$ microns (mean $93 \pm 36.9$ microns of the corneal stroma). Conclusions: Donor keratocites are activated up to 7 weeks after DSAEK. Several corneal folds are present in proximity to the donor-receptor interface after DSAEK. Further evaluation of these findings is justified to determine its clinical significance.
\end{abstract}

KEY WORDS: Confocal. Endothelial. DSAEK. Interface. Transplant. Keratocyte.

\section{Resumen}

Objetivo: Evaluar los hallazgos cicatriciales tempranos en la córnea de pacientes operados de DSAEK (Descemet's Stripping Automated Endothelial Keratoplasty) mediante microscopía confocal in vivo. Método: Se incluyeron 15 ojos de 15 pacientes. Se realizó microscopía confocal (Confoscan 4, Fortune Technologies, Italy) entre las 4 y las 7 semanas después de la cirugía de DSAEK. Las mediciones se realizaron desde el endotelio al epitelio corneal utilizando el programa Navis $\circledast$ software (NIDEK, Multi-Instrument Diagnostic System, Japan). Resultados: La interface donador-receptor se encontró a $114 \pm 12.4$ micras en promedio. Se comenzaron a observar pliegues en el estroma a $111.1 \pm 3.5$ micras desde el endotelio corneal hasta $286 \pm 94$ micras (promedio de $175 \pm 90.5$ micras del estroma corneal). Se comenzó a observar activación de queratocitos en el tejido donador a $12 \pm 1.4$ micras desde el endotelio hasta $105 \pm 38.2$ micras (promedio de $93 \pm 36.9$ micras del estroma corneal). Conclusiones: Los queratocitos del tejido donador se encontraron activados hasta 7 semanas después de la cirugía de DSAEK. En la proximidad de la interface donador-receptor se encontraron grandes pliegues en el estroma después de cirugía de DSAEK. Se requieren futuras evaluaciones para determinar la significancia clínica de estos hallazgos.

PALABRAS CLAVE: Confocal. Endotelial. DSAEK. Trasplante. Queratocito.

\author{
Correspondence: \\ *Manuel Ramírez \\ Vicente García Torres, 46 \\ San Lucas Coyoacán, \\ C.P. 04030, Ciudad de México, México \\ E-mail: mramirezfdz@gmail.com
}

Date of reception: 11-11-2017

Date of acceptance: 14-02-2018

DOI: $10.24875 / C I R U E . M 18000018$
Cir Cir. 2018;86:110-113

Contents available at PubMed www.cirugiaycirujanos.com 
Introduction

Endothelial transplantation using the Descemet's Stripping Automated Endothelial Keratoplasty (DSAEK) technique has demonstrated to be a good surgical alternative to solve corneal pathologies where the corneal endothelium is damaged but the corneal stroma is intact, with a donor graft being required for the resolution of the problem ${ }^{1,2}$. Furthermore, it has been reported to be an option in the treatment of patients who experience failure after penetrating keratoplasty ${ }^{3}$.

The purpose of the present study is to evaluate early corneal scarring findings in DSAEK-operated patients using confocal microscopy in vivo.

\section{Method}

Fifteen eyes from 15 patients underwent corneal endothelium transplantation using the DSAEK techni$q^{2} e^{2}$. All endothelial grafts were obtained on request from the eye bank, each with a thickness of $100 \mathrm{mi}$ crons. Preoperative diagnoses of the patients undergoing DSAEK surgery were nine bullous keratopathies secondary to pseudophakia and six Fuchs dystrophies, also pseudophakic. Average age was $72.1 \pm$ 4.9 years (range, 63 to 76 years). Seven patients were males and eight were females.

Confocal microscopy in vivo examination was carried out on all patient corneas, depending on corneal transparency, between 4 and 7 weeks after the DSAEK procedure using a confocal slit microscope (Confisca 4; Fortune Technologies, Vigonza, Italy). On each confocal microscopy examination, a sequence of digital images was obtained, which consisted of four consecutive corneal thickness total depth scans, with a scan being equivalent to obtaining images from the endothelium to the epithelium and back to the endothelium, i.e., from the posterior to the anterior view, and then again to the posterior view, in order to enable moving along the central corneal thickness Z-axis. The Z-ring device (Confoscan, Fortune Technologies, Italy) was used, which maintains contact with the cornea in order to obtain reliable thickness measurements without the presence of anteroposterior movement of the eyeball.

Images were automatically captured in a computer hard drive. Measurements were made from the endothelium to the corneal epithelium using the Navis program, v. 3.5.0. (NIDEK, Multi-Instrument Diagnostic System, Japan).

\section{Results}

Corneal transparency was observed between 4 and 7 weeks after the DSAEK surgery in all operated corneas. Visual capacity was $20 / 50$ or more in all patients 7 weeks after the procedure.

Donor-receptor interface was found due to the presence of hyper-reflective particles at $114 \pm 12.4 \mathrm{mi}$ crons (from endothelium to epithelium) on average (Fig. 1). Stromal folds began to be observed at 111.1 \pm 3.5 microns from the corneal endothelium to up to $286 \pm 94$ microns towards the corneal epithelium (with an average of $175 \pm 90.5$-micron stromal thickness, with the presence of folds) (Fig. 2). Donor tissue keratocyte activation began to be observed at $12 \pm 1.4$ microns from the endothelium to up to $105 \pm 38.2$ microns towards the corneal epithelium (at an average of $93 \pm 36.9$-micron stroma thickness, with keratocyte activation) (Fig. 3).

\section{Discussion}

Endothelial transplantation is a technique that is taking an important place among the surgical resources for the treatment of corneal pathologies where the only damaged structure is the corneal endothelium and replacement of the entire cornea is therefore not necessary, as in the case of penetrating keratoplasty ${ }^{2,4}$. The DSAEK technique has demonstrated its efficacy even in the management of primary failures in penetrating keratoplasties ${ }^{3}$. Furthermore, favorable results have been reported in terms of visual acuity and postoperative satisfaction of patients undergoing endothelial transplantation with the DSAEK technique ${ }^{1,5}$.

In the present study, early scarring changes were assessed in vivo in corneal tissue after DSAEK surgery. Confocal microscopy was carried out until there was adequate transparency on each one of the operated corneas, in order for the images of their different structures to be adequately evaluable, as well as to enable thickness measurements to be reliably performed without the presence of corneal edema.

Previous confocal microscopy studies in patients operated on using DSAEK report the presence of "fog" in the donor-recipient interface, as well as the presence of particles in said interface, similar to those found in refractive surgery ${ }^{6-8}$. Prasher et al. ${ }^{9}$ also reported the presence of particles in the donor-recipient interface 6 months after surgery, as well keratocyte activation in the anterior stroma, in contrast with the present study, where keratocyte activation was found in the 


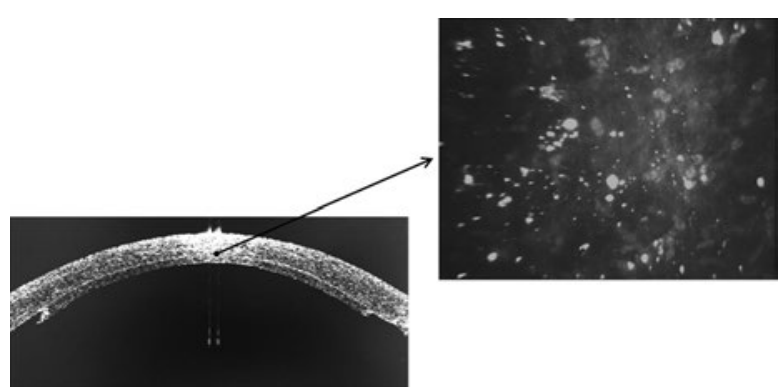

Figure 1. Confocal microscopy image of the corneal stroma (right), where the presence of particles is observed in the donor-recipient interface at $114 \pm 12.4$ microns from the endothelium to the corneal epithelium $(340 \times 255 \mu \mathrm{m})$. In addition, an optical coherence tomography image (left) of the same patient is presented; the arrow points at the donor-recipient interface.

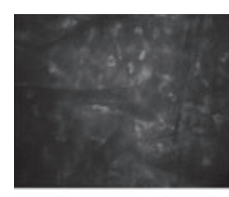

Ends: $286 \pm 94.0$ microns from endothelium

Stromal average thickness with activated keranocytes: $175 \pm 90.5$ microns
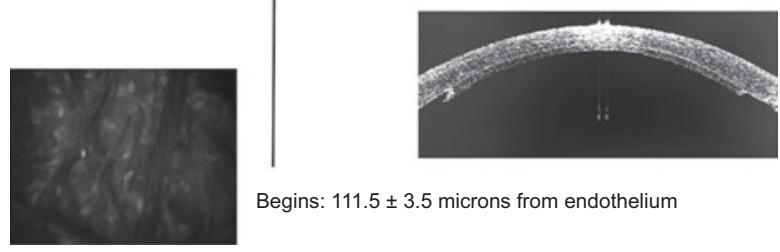

Begins: $111.5 \pm 3.5$ microns from endothelium

Figure 2. Confocal microscopy images (left; $340 \times 255 \mu \mathrm{m}$ ) illustrating the depth at which the folds in the corneal stroma begin and end, as well as its average thickness, with the presence of folds; the arrow and the optical coherence tomography image (right) show how the measurements were made from corneal endothelium to epithelium.

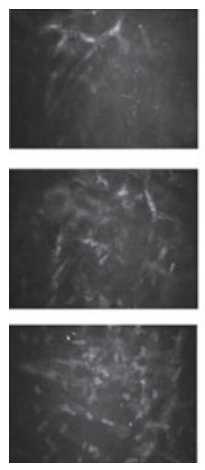

Ends: $105 \pm 38.2$ microns from endothelium

Stromal average thickness with activated keranocytes: $93 \pm 36.9$ microns

Figure 3. Confocal microscopy images $(340 \times 255 \mu \mathrm{m})$ (left) illustrating the depth at which the presence of keratocyte activation in the corneal stroma begins and ends, as well as its average thickness, with the presence of keratocyte activation; the arrow and the optical coherence tomography image (right) show how the measurements were made from corneal endothelium to epithelium.

donor stroma, with the difference that we carried out the confocal microscopy procedure at between 4 and 7 weeks postoperatively. Keratocyte activation on confocal microscopy has been reported in the postoperative period of all techniques that elicit a scarring reaction of the corneal stroma, as in refractive surgery in all its varieties ${ }^{8,10-14}$. Keratocyte activation has also been reported in the case of physical procedures, such as cross-linking ${ }^{15,16}$. The corneal stroma depth at which keratocytes are activated, as well as their permanen$c e$, varies depending on the different procedures.

The presence of particles in the interface has been a constant confocal microscopy finding in all surgical techniques where an interface is generated in the corneal stroma, as in the case of Laser Assisted In Situ Keratomileusis (LASIK) surgery ${ }^{8,10,17}$, regardless of the use of microkeratome, or femtosecond laser ${ }^{12}$, as well as in deep lamellar keratoplasty ${ }^{18}$.

On the other hand, corneal stroma folds have also been frequently reported with confocal microscopy studies in the postoperative period of corneal surgeries involving the presence of an interface in the corneal stroma, such as LASIK surgery ${ }^{17,19}$ and deep lamellar keratoplasty ${ }^{18,20}$.

\section{Conclusions}

The present study focused completely on early scarring findings on confocal microscopy in patients after endothelial transplantation using the DSAEK technique, which showed both early keratocyte activity and the presence of particles in the donor-receptor interface, as well as folds in the corneal stroma. Clinical results were not the purpose of this study.

\section{Ethical responsibilities}

Protection of people and animals. The authors declare that no experiments have been conducted in humans or animals for this research.

Confidentiality of data. The authors declare having followed the protocols of their work center on the publication of patient data.

Right to privacy and informed consent. The authors declare that no patient data appear in this article.

\section{Conflicts of interest}

No author has any type of conflict of interest in this article.

\section{Funding}

The funding of this study was internal, granted by the affiliation institution: Department of Cornea and Refractive Surgery, Asociación para Evitar la Ceguera 
en México, Hospital Luis Sánchez Bulnes, Universidad Nacional Autónoma de México.

\section{References}

1. Koenig SB, Covert DJ, Dupps WJ Jr., Meisler DM. Visual acuity, refractive error, and endothelial cell density six months after Descemet stripping and automated endothelial keratoplasty (DSAEK). Cornea. 2007; 26:670-4

2. Cursiefen C, Kruse FE. Descemet's stripping with automated endothelial keratoplasty (DSAEK). Ophthalmologe. 2008;105:183-90, 192.

3. Covert DJ, Koenig SB. Descemet stripping and automated endothelial keratoplasty (DSAEK) in eyes with failed penetrating keratoplasty. Cornea. 2007;26:692-6.

4. Melles GR. Posterior lamellar keratoplasty: DLEK to DSEK to DMEK. Cornea. 2006;25:879-81.

5. Bachmann BO, Pogorelov $P$, Kruse FE, Cursiefen C. Patient satisfaction after posterior lamellar keratoplasty (DSAEK). Klin Monbl Augenheilkd. 2008; 225:577-81.

6. Kobayashi A, Mawatari $Y$, Yokogawa H, Sugiyama K. In vivo laser confocal microscopy after descemet stripping with automated endothelial keratoplasty. Am J Ophthalmol. 2008;145:977-85.

7. Ferrari G, Reichegger V, Ludergnani L, Delfini E, Macaluso C. In vivo evaluation of DSAEK interface with scanning-laser confocal microscopy. BMC Ophthalmol. 2012;12:32.

8. Vesaluoma M, Perez-Santonja J, Petroll WM, Linna T, Alio J, Tervo T. Corneal stromal changes induced by myopic LASIK. Invest Ophthalmol Vis Sci. 2000;41:369-76.

9. Prasher P, Muftuoglu O, Bowman RW, McCulley JP, Petroll WM, Cavanagh HD, et al. Tandem scanning confocal microscopy of cornea after descemet stripping automated endothelial keratoplasty. Eye Contact Lens. 2009;35:196-202.
10. Mitooka K, Ramirez M, Maguire LJ, Erie JC, Patel SV, McLaren JW, et al. Keratocyte density of central human cornea after laser in situ keratomileusis. Am J Ophthalmol. 2002;133:307-14.

11. Ramírez M, Hernández-Quintela E, Naranjo-Tackman R. Hallazgos estromales in vivo en pacientes operados de PRK con el uso de mitomicina-C. Rev Mex Oftalmol. 2009;83:206-8.

12. Ramírez M, Hernández-Quintela $E$, Naranjo-Tackman R. A comparative confocal microscopy analysis after LASIK with the IntraLase femtosecond laser vs Hansatome microkeratome. J Refract Surg. 2007;23:305-7.

13. Ramírez M, Hernández-Quintela E, Naranjo-Tackman R. Epi-LASIK: a confocal microscopy analysis of the corneal epithelium and anterior stroma. Ophthalmic Surg Lasers Imaging. 2012;43:319-22.

14. Erie JC, Patel SV, McLaren JW, Maguire LJ, Ramirez M, Bourne WM. Keratocyte density in vivo after photorefractive keratectomy in humans. Trans Am Ophthalmol Soc. 1999;97:221-36; discussion 236-40.

15. Dhaliwal JS, Kaufman SC. Corneal collagen cross-linking: a confocal, electron, and light microscopy study of eye bank corneas. Cornea. 2009; 28:62-7.

16. Ramírez M, Hernández-Quintela E, Naranjo-Tackman R. Early confocal microscopy findings after cross-linking treatment. Arch Soc Esp Oftalmol. 2013;88:179-83

17. Ramírez M, Hernández-Quintela E, Sánchez-Huerta V, Naranjo-Tackman R. Confocal microscopy of corneal flap microfolds after LASIK. J Refract Surg. 2006;22:155-8.

18. Marchini G, Mastropasqua L, Pedrotti E, Nubile M, Ciancaglini M, Sbabo A. Deep lamellar keratoplasty by intracorneal dissection: a prospective clinical and confocal microscopic study. Ophthalmology. 2006;113:1289-300.

19. Carpel EF, Carlson KH, Shannon S. Fine lattice lines on the corneal surface after laser in situ keratomileusis (LASIK). Am J Ophthalmol. 2000;129:379-80.

20. Ramírez M, Naranjo-Tackman R. Comparación postoperatoria mediante microscopia confocal de queratoplastía lamelar profunda realizada con dos técnicas quirúrgicas: disección por burbuja de aire vs láser de femtosegundos. Rev Mex Oftalmol. 2008;82:34-7. 